\title{
Chemigation with Benomyl and Fluazinam and their Fungicidal Effects in Soil for White Mold Control on Dry Beans
}

\author{
Rogério F. Vieira*, Cleide M. F. Pinto \& Trazilbo J. de Paula Júnior \\ Empresa de Pesquisa Agropecuária de Minas Gerais, Cx. Postal 216, CEP 36571-000 Viçosa, MG, fax: (031) 3891-5224, \\ e-mail: rfvieira@homenet.com.br
}

(Aceito para publicação em 18/03/2003)

Autor para correspondência: Rogério F. Vieira

VIEIRA, R.F., PINTO, C.M.F. \& PAULA JÚNIOR, T.J. de. Chemigation with benomyl and fluazinam and their fungicidal effects in soil for white mold control on dry beans. Fitopatologia Brasileira 28:245-250. 2003.

\begin{abstract}
The effectiveness of fungicides in controlling white mold (Sclerotinia sclerotiorum) of dry beans (Phaseolus vulgaris) was evaluated when they were applied through irrigation water directly onto the plants or only to the soil. Two field trials were installed in April 1998 and April 1999 in Viçosa, MG. Trials were conducted as a $(2 \times 3)+1$ factorial: two fungicides $x$ three application modes + one untreated control. The fungicides were benomyl $\left(1.0 \mathrm{~kg}\right.$ a.i. ha $\left.{ }^{-1}\right)$ and fluazinam $\left(0.51\right.$ a.i. ha $\left.{ }^{-1}\right)$. The three application modes were: (a) by backpack sprayer $\left(6671 \mathrm{ha}^{-1}\right)$, (b) by garden watering-cans simulating sprinkler irrigation with $35,0001 \mathrm{ha}^{-1}$ of water, and (c) by garden watering-cans applying water between the rows and near the soil

surface in $35,0001 \mathrm{ha}^{-1}$ of water. In 1998, fungicides were applied at 43 and 54 days after emergence (DAE); in 1999, at 47 and 61 DAE. Both fungicides were similarly effective on white mold control when applied by either chemigation or backpack sprayer, resulting in yields $21 \%$ higher than untreated control. Only fluazinam provided disease control when applications were made only in soil. Chemigation provided white mold control equivalent to that of backpack sprayer in terms of incidence, severity and number of diseased pods. Consequently, yield differences between these application methods were not significant.

Additional keywords: Phaseolus vulgaris, Sclerotinia sclerotiorum, fungicides, irrigation.

\section{RESUMO}

Quimigação com benomyl e fluazinam e seus efeitos no solo no controle do mofo-branco em feijoeiro

O objetivo deste estudo foi avaliar a eficiência de fungicidas aplicados via água de irrigação sobre as plantas ou apenas no solo no controle do mofo-branco (Sclerotinia sclerotiorum) do feijoeiro (Phaseolus vulgaris). Dois experimentos foram instalados em abril de 1998 e de 1999, em Viçosa, MG. Os experimentos foram conduzidos num fatorial $(2 \times 3)+1$ : dois fungicidas $\mathrm{x}$ três modos de aplicação + uma testemunha sem fungicida. Os fungicidas foram benomyl $\left(1,0 \mathrm{~kg} \mathrm{ha}^{-1}\right)$ e fluazinam $\left(0,51 \mathrm{ha}^{-1}\right)$. Os três modos de aplicação foram: (a) com pulverizador costal $\left(6671\right.$ ha $\left.^{-1}\right)$, (b) com regador, simulando irrigação por aspersão com 35.0001 ha $^{-1}$ de água,

e (c) com regador, aplicando-se a água $\left(35.0001 \mathrm{ha}^{-1}\right)$ entre as fileiras do feijoeiro e rente ao solo. Em 1998, os fungicidas foram aplicados aos 43 e 54 dias após a emergência (DAE); em 1999, aos 47 e 61 DAE. Ambos os fungicidas foram eficientes no controle do mofobranco quando aplicados pela água de irrigação sobre as plantas ou por pulverizador, resultando em aumento de produtividade de $21 \%$. Apenas fluazinam proporcionou controle da doença quando as aplicações foram feitas no solo. A quimigação proporcionou controle do mofo-branco semelhante ao obtido com o pulverizador em relação à incidência, à severidade e ao número de vagens doentes. Conseqüentemente, os rendimentos de feijão alcançados com os dois métodos de aplicação foram semelhantes.
\end{abstract}

\section{INTRODUCTION}

Approximately $35 \%$ of dry beans (Phaseolus vulgaris L.) harvested in the State of Minas Gerais are produced in sprinkler irrigated areas during fall-winter period. One of the most important diseases affecting dry beans in these areas is white mold caused by Sclerotinia sclerotiorum (Lib.) de Bary. This fungus can infect up to 408 plant species, including tomato (Lycopersicon esculentum Mill.), potato (Solanum tuberosum L.), pea (Pisum sativum L.), lettuce (Lactuca sativa L.), and many weeds (Boland \& Hall, 1994). Sclerotinia sclerotiorum survives from year to year by means of sclerotia on plant debris or in the soil where they remain alive and infective for three years or longer (Schwartz et al., 1989). Transporting infected plant debris, seed, or soil containing sclerotia to uninfested areas will spread the disease. A sclerotium may germinate directly by producing white mycelial strands, but more commonly sclerotia germinate by producing one or more stipes that grow upward from a soil depth of less than $5 \mathrm{~cm}$. Upon reaching the surface, the tip of the stipes develop apothecia. Each apothecium produces millions of ascospores. These are periodically released and airborne dispersed to nearby plants (Schwartz et al., 1989). Epidemics of white mold occur only after flowering (Abawi \& Grogan, 1979). Primary infections are caused mainly by ascospores that germinate on fallen flower petals that adhere to stems or petioles, apparently because the ascospores require an exogenous energy source to infect healthy bean plants. According to Tu (1987), other modes of primary infection are: ascospore contaminated leaves in contact with soil, leaves in contact with sclerotia exposed on the soil 
surface, and infections associated with injuries. Disease initiation is favored by cool and damp soil. Secondary spread occurs by plant to plant contact.

Several fungicides are active against this disease. In general, it is recommended that fungicides be applied during early bloom and if conditions continue to be favorable to disease, an additional application may be necessary. Timing of fungicidal application is critical to protect blossoms from infection. The fungicide must be applied in sufficient water to provide thorough coverage of blossoms, stems and leaves, especially those closest to the soil surface. Fungicide application by aircraft has not controlled white mold properly because fungicide does not penetrate deeply into the plant canopy (Tu, 1989). Chemigation, the application of chemicals through irrigation systems, has been used successfully to apply virtually all types of agricultural chemicals (Vieira, 1994). Application of the fungicides vinclozolin, procymidone, and fluazinam through irrigation water is the most common method used on sprinkler irrigated areas of Minas Gerais for white mold control. Research done in the United States and Brazil show that this method efficiently controls the disease (Vieira \& Sumner, 1999) and can be more efficient in some situations than conventional methods (Oliveira et al., 1995).

Prescription application, reduced application costs and operator hazards, no soil compaction, and no vine injury are important advantages of chemigation over ground sprays (Vieira \& Sumner, 1999). If pesticides are applied through irrigation systems, savings of $29-78 \%$ in application costs may result (Csinos et al., 1986). However, the high volume of water applied by irrigation means that more fungicide reaches the soil than with application by conventional methods. According to Vieira \& Sumner (1999), reduction of fungicide residue on foliage of crops caused by the large volume of water used by chemigation might usually be offset by the following factors: fungicide is applied at the time of maximum leaf wetness when fungi are most active; nearly complete coverage is achieved by redistribution on leaves with successive droplets; great reduction of inoculum in field by complete coverage of plants and plant residue on soil surface; better control of soil borne pathogens; and more uniform field distribution. The objective of this study was to determine the efficacy of two fungicides applied through irrigation water and the effectiveness of the fungicides when applied only to the soil.

\section{MATERIALS ANDMETHODS}

The trials were conducted during 1998-99 at Viçosa Federal University, Minas Gerais, in a field naturally infested with sclerotia of $S$. sclerotiorum. The soil characteristics were: $53 \%$ clay, $24 \%$ silt, $23 \%$ sand, and $\mathrm{pH}\left(\mathrm{H}_{2} 0\right)=5.8$. The vine bean cultivar Pérola (type III) was sown in rows spaced $0.5 \mathrm{~m}$ apart. Plots of four $5 \mathrm{~m}$-long rows were over seeded during the second half of April (fall) and, where needed, densities were adjusted by thinning to approximately $12-15$ plants per meter 2-3 weeks after seedling emergence. The trials were conducted as a $(2 \times 3)+1$ factorial: two fungicides $\times$ three application modes + one untreated control. The fungicides were benomyl (Benlate $500 \mathrm{WP}, 1.0 \mathrm{~kg}$ a.i. ha ${ }^{-1}$ ) and fluazinam (Frowncide 500 SC, 0.51 a.i. ha ${ }^{-1}$ ). The three application modes were: by a backpack sprayer equipped with one cone nozzle delivering 6671 ha $^{-1}$ of water; by garden watering-cans with capacity for 101 of water, simulating sprinkler irrigation using 35,000 l of water per hectare; and by garden watering-cans applying water between the rows and near the soil surface, avoiding wet leaves and flowers, in 35,000 l of water per hectare. Holes in the sprinkler heads on the garden watering-cans were reduced by using a polyethylene substance. Thus, watering took between 4 and 5 min on each plot, simulating water being applied by center pivot. The seven treatments were arranged in a randomized complete block design with six replications. Supplementary irrigation using overhead sprinkler was applied to achieve good crop growth and conditions suitable for disease development. Approximately 22 days after emergence (DAE) $42 \mathrm{~kg} \mathrm{ha}^{-1}$ of nitrogen as urea were distributed along the rows. Weeds were controlled by hand hoeing and with a commercial mixture of the herbicides fomesafen $\left(250 \mathrm{~g} \mathrm{a.i.}^{-1}\right)$ and fluazifop-p-butyl (200 g a.i. ha $\left.{ }^{-1}\right)$, insects were controlled, when needed, with deltamethrin $\left(80 \mathrm{~g}\right.$ a.i. $\left.\mathrm{ha}^{-1}\right)$. A solution of molbdenum ( $80 \mathrm{~g} \mathrm{ha}^{-1}$ ), as sodium molbdate, was sprayed on foliage approximately $30 \mathrm{DAE}$. In 1998, one application of the insecticide cartap $\left(0.5 \mathrm{~kg}\right.$ a.i. ha- $\left.{ }^{-1}\right)$ for control of leafminers (Lyriomyza sp.) was made 29 DAE. In 1999, all plots were treated with the fungicide azoxystrobin $\left(80 \mathrm{~g}^{\mathrm{a}}\right.$.i. $\left.\mathrm{ha}^{-1}\right)$ at 34 and 55 DAE to protect against foliar diseases. In 1998, fungicides for white mold control were applied at 43 and 54 DAE. At 43 DAE, all plants had at least one open flower. At 54 DAE, the oldest pods were $2 \mathrm{~cm}$ long. In 1999, fungicides were applied at 47 and 61 DAE. The first application was made when approximately $70 \%$ of the plants had at least one open flower. At 61 DAE, the oldest pods were $5 \mathrm{~cm}$ long.

For foliar diseases the evaluation was made based on a 1-9 scale of severity adapted from Van Schoonhoven \& Pastor Corrales (1987), where 1.1 to 2.5 (low), 2.6 to 4.1 (low/moderate), 4.2 to 5.7 (moderate), 5.8 to 7.3 (moderate/severe), and 7.4 to 9.0 (severe). In both years bean plants were harvested 111 DAE. One square meter of each plot was harvested separately for white mold evaluation. The plants were rated for severity of white mold on a scale of $0,1,2,3$, and 4 representing $0,1-25$, 26-50, 51-75, and 76-100\% of stems and branches with disease symptoms (Hall \& Phillips, 1996). Disease incidence was calculated as the percentage of plants with symptoms on stems or branches. Percentage of pods with symptoms of white mold was also determined. Three square meters of each plot were harvested to estimate 100-seed weight, and weight and number of sclerotia larger than $2 \mathrm{~mm}$ mixed with seeds. Yield data were based on weight of seeds at 12-13\% moisture (w/w) harvested in four square meters (included one square meter harvested for disease evaluation). Collected data were subjected to statistical analysis of variance and means were compared using the least significant difference (LSD) at the 5\% level of probability. For comparison of the treatments against the untreated control the Dunnett's test was used (Chew, 1976). 


\section{RESULTS}

\section{Trial}

Besides white mold, angular leaf spot caused by Phaeoisariopsis griseola (Sacc.) Ferraris was detected late in the season at a low level. There was no significant difference among treatments regarding angular leaf spot severity. White mold was not detected in the untreated control until 60 DAE. At 70 DAE, an average of 22 plants was detected with symptoms of the disease in the two central rows $\left(5 \mathrm{~m}^{2}\right)$ of the untreated plots. At harvest, $51.9 \%$ of plants were diseased (Table 1). Fungicide $\mathrm{x}$ application mode interaction effects were significant for incidence and severity. Fluazinam was superior to benomyl in reducing incidence and severity when both were applied only to the soil (Table 1). Both chemigation and backpack sprayer application of benomyl provided a significantly lower white mold incidence and severity compared with application of benomyl in soil. Only plants sprayed with benomyl showed a lower incidence of white mold than those on the untreated control (Table 1). In relation to severity level, benomyl applied either by a backpack sprayer or chemigated, and fluazinam applied by a backpack sprayer, provided better control compared with the control (Table 1). Fungicide and fungicide $\mathrm{x}$ application mode effects were not significant for diseased pods. Within modes of application, the number of diseased pods harvested in plots treated by the conventional method was lower than in those where fungicides were applied to the soil, but neither treatments differed significantly from chemigation (Table 1). Percentages of diseased pods were lower when benomyl was applied either by chemigation $(4.2 \%)$ or by backpack sprayer $(4.1 \%)$ when compared with the control (13.1\%).

Fungicide and application mode $\mathrm{x}$ fungicide effects on yield were not significant. The F test was significant for application mode effects on yield, but the Fisher's protected LSD test did not show differences among means, which varied from 2,284 $\mathrm{kg} \mathrm{ha}^{-1}$ (fungicide applied in soil) to 2,600 kg ha-1 (backpack sprayer) (Table 2). Benomyl applied by a backpack sprayer $\left(2,683 \mathrm{~kg} \mathrm{ha}^{-1}\right)$ increased yield compared with the control $\left(2,157 \mathrm{~kg} \mathrm{ha}^{-1}\right)$. The $\mathrm{F}$ test was significant only for application mode effects for weight and number of sclerotia mixed with seeds. Production of sclerotia on plots treated by a backpack sprayer was lower than on plots where fungicides were applied in soil, but neither treatment differed significantly from chemigation (Table 2). Weight and number of sclerotia from plants sprayed with fluazinam were significantly reduced compared with the control (Table 2). One hundred-seed weight was not affected significantly by treatments.

\section{Trial}

First symptoms of white mold were observed only 78 DAE, but disease incidence increased quickly, achieving nearly $100 \%$ of plants in control plots at harvest (Table 1). Fungicide $\mathrm{x}$ application mode effects were not significant for any variable. Neither fungicide nor application mode effects were significant for incidence. Plants treated by a backpack sprayer, regardless of fungicide, and those treated by fluazinam chemigated showed significantly less white mold incidence compared with untreated plants (Table 1). Severity level was lower with fluazinam (1.49) than it was with benomyl (1.87). Spray applications of fungicides were more effective in reducing white mold severity than were applications to the soil, but neither treatment differed significantly from chemigation (Table 1). There was no difference in white mold severity between plants on plots treated by fungicides applied in soil and plants on untreated plots (Table 1). Neither fungicide nor application mode affected pods diseased significantly. All treatments, except benomyl applied in soil, decreased pods diseased compared with the control (Table 1).

Fungicide, application mode, and fungicide $\mathrm{x}$ application mode effects were not significant for yield and weight and number of sclerotia mixed with seeds. Except for benomyl applied to the soil, the yield of untreated control $\left(2,369 \mathrm{~kg} \mathrm{ha}^{-1}\right)$ was lower than those attained by fungicide treatments (Table 2 ). The highest number and weight of sclerotia were produced on untreated plants, significantly more than in all treatment except plants that were chemigated with benomyl (Table 2). Again, there was a consistent trend of fewer sclerotia being produced by plants treated by backpack sprayer than by chemigation. One hundred seed weight was not affected significantly by treatments.

Fungicide $\mathrm{x}$ application mode effects were significant for angular leaf spot severity (Table 3). Benomyl was superior to fluazinam only on chemigation. Within fluazinam, a lower level of angular leaf spot occurred on plants treated by conventional method than on those treated either by chemigation or by fungicide applied to the soil. Within benomyl, application by backpack sprayer and by chemigation was equivalent and superior to application in soil. Plants treated with benomyl, regardless of application modes, and fluazinam applied by conventional method, were less infected by angular leaf spot than the control.

\section{DISCUSSION}

Chemigation of benomyl and fluazinam was as effective for control of white mold as their application by backpack sprayer at the same rate. These results agree with those reported for benomyl in Idaho in which a lateral roll irrigation system was used (Forster \& Samson, 1984). In this study, chemigation of benomyl (1.12 kg a.i. ha-1) was compared only with the untreated control and bean yield was increased. In Guaíra, São Paulo, treatments of benomyl alone or mixed with other fungicides were somewhat more efficient when they were applied through a center pivot $(3.1 \mathrm{~mm})$ than by a $\mathrm{CO}_{2}$ sprayer $\left(3001 \mathrm{ha}^{-1}\right)$. This better control provided by chemigation, however, did not increase yield significantly (Oliveira et al., 1995).

Under conventional application fungicides are normally applied in 30 to $1,0001 \mathrm{ha}^{-1}$ of water. By chemigation, on the other hand, the minimum volume of water applied by some center pivots is approximately $2.5 \mathrm{~mm}\left(25,0001 \mathrm{ha}^{-1}\right.$ of water $)$, which exceeds by at least 25 times the maximum volume of 
R.F. Vieira et al.

TABLE 2 - Yield and weight and number of sclerotia of Sclerotinia sclerotiorum mixed with seeds of beans (Phaseolus vulgaris) treated with fungicides $^{\mathrm{a}}$ via three modes of application in Viçosa, MG, in 1998 and 1999

\begin{tabular}{|c|c|c|c|c|c|c|c|c|c|c|}
\hline \multirow[t]{2}{*}{ Treatment } & \multirow{2}{*}{$\begin{array}{l}\text { Water volume } \\
\qquad\left(1 \mathrm{ha}^{-1}\right)\end{array}$} & \multicolumn{2}{|c|}{ Yield (kg ha $\left.{ }^{-1}\right)$} & \multirow[t]{2}{*}{ Average $^{b}$} & \multicolumn{2}{|c|}{$\begin{array}{l}\text { Weight of sclerotia } \\
\qquad\left(\mathrm{g} / 3 \mathrm{~m}^{2}\right)\end{array}$} & \multirow[t]{2}{*}{ Average $^{c}$} & \multicolumn{2}{|c|}{$\begin{array}{c}\text { Number of sclerotia } \\
\left(3 \mathrm{~m}^{2}\right)\end{array}$} & \multirow[t]{2}{*}{ Average } \\
\hline & & Fluazinam & Benomyl & & Fluazinam & Benomyl & & Fluazinam & Benomyl & \\
\hline \multicolumn{11}{|l|}{1998} \\
\hline Untreated control & \multicolumn{4}{|c|}{2,157} & \multicolumn{2}{|c|}{5.58} & \multicolumn{4}{|c|}{355.2} \\
\hline Fungicide in soil & 35,000 & 2,332 & 2,236 & 2,284 & 4.85 & 6.08 & $5.47 \mathrm{a}$ & 360.7 & 414.8 & $387.7 \mathrm{a}$ \\
\hline Chemigation & 35,000 & 2,592 & 2,559 & 2,575 & 3.73 & 5.07 & $4.40 \mathrm{ab}$ & 250.2 & 374.7 & $312.4 \mathrm{ab}$ \\
\hline Backpack sprayer & 667 & 2,517 & $2,683^{\mathrm{d}}$ & 2,600 & $1.82^{\mathrm{d}}$ & 3.02 & $2.42 \mathrm{~b}$ & $141.0^{\mathrm{d}}$ & 227.3 & $184.2 \mathrm{~b}$ \\
\hline Average & & 2,480 & 2,493 & & 3.47 & 4.72 & & 250.6 & 338.9 & \\
\hline \multicolumn{11}{|l|}{1999} \\
\hline Untreated control & \multicolumn{4}{|c|}{2,369} & \multicolumn{2}{|c|}{6.91} & \multicolumn{4}{|c|}{600.2} \\
\hline Fungicide in soil & 35,000 & $2,826^{\mathrm{d}}$ & 2,703 & 2,764 & $2.36^{\mathrm{d}}$ & $2.99^{d}$ & 2.67 & $152.0^{\mathrm{d}}$ & $229.5^{\mathrm{d}}$ & 190.7 \\
\hline Chemigation & 35,000 & $2,968^{\mathrm{d}}$ & $2,751^{\mathrm{d}}$ & 2,859 & $1.39^{\mathrm{d}}$ & 4.11 & 2.75 & $114.2^{\mathrm{d}}$ & 339.0 & 226.6 \\
\hline Backpack sprayer & 667 & $2,968^{\mathrm{d}}$ & $2,873^{\mathrm{d}}$ & 2,921 & $1.07^{\mathrm{d}}$ & $2.77^{\mathrm{d}}$ & 1.92 & $65.5^{\mathrm{d}}$ & $174.5^{\mathrm{d}}$ & 120.0 \\
\hline Average & & 2,921 & 2,776 & & 1.60 & 3.29 & & 110.6 & 247.7 & \\
\hline
\end{tabular}

a Two applications of Frowncide $500 \mathrm{SC}\left(0.51\right.$ a.i. ha $\left.{ }^{-1}\right)$ or Benlate 500 (1.0 kg a.i. ha $\left.{ }^{-1}\right)$ at 43 and 54 DAE (1998) or at 47 and 61 DAE (1999).

${ }^{b}$ In 1998, the F test was significant for modes of application, but Fisher's protected LSD test did not show differences among means.

' Means separation by Fisher's protected LSD test at 5\% level.

'Different from untreated control by Dunnett's test at $5 \%$ level.

TABLE 1 - White mold incidence, severity and diseased pods at harvest of beans (Phaseolus vulgaris) treated with fungicides ${ }^{\mathrm{a}}$ via three modes of application, in Viçosa, MG, in 1998 and 1999

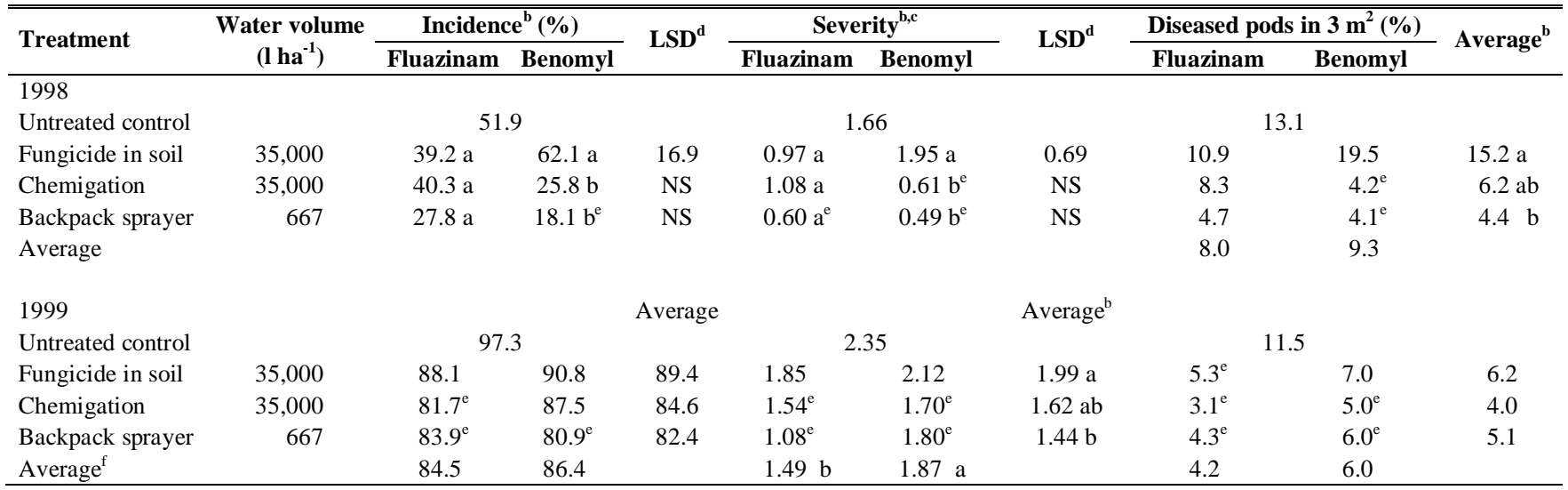

a Two applications of Frowncide $500 \mathrm{SC}\left(0.51\right.$ a.i. ha $\left.{ }^{-1}\right)$ or Benlate 500 (1.0 kg a.i. ha $\left.{ }^{-1}\right)$ at 43 and 54 DAE (1998) or at 47 and 61 DAE (1999).

b Means separation by Fisher's protected LSD test at $5 \%$ level.

${ }^{\mathrm{c}}$ Rated at harvest on a scale of $0,1,2,3$, and 4 representing $0,1-25,26-50,51-75$, and 76-100\% of stems and branches with disease symptoms.

'For comparison of fungicides within modes of application, Fisher's protected LSD $(\mathrm{P}<0.05)$. NS = not significant.

e Different from untreated control by Dunnett's test at $5 \%$ level.

${ }^{\mathrm{f}}$ Means separation by $\mathrm{F}$ test.

water used by conventional ground sprayers. Consequently, residues remaining on the foliage immediately after fungicide application (Brenneman et al., 1990) or one or two days later (McMaster \& Douglas, 1976) are much greater when a fungicide is ground-sprayed and aircraft-applied than when it is distributed through irrigation water (McMaster \& Douglas, 1976; Brenneman et al., 1990). Working with peanut (Arachis hypogaea L.), Brenneman et al. (1990) showed that although chemigation resulted in less deposition of chlorothalonil than ground spray, differences were five (upper canopy layer) to thirty (lower canopy layer) times lower than might be anticipated on the basis of spray volume alone. This fact, in addition to relatively more uniform distribution, nearly complete coverage of plant and soil, providing great reduction of inoculum in the field, might help to explain chemigation efficiency for the control of some diseases (Vieira \& Sumner, 1999). Furthermore, systemic fungicides seem to be able to offset the potential of being washed from foliage when applied by chemigation by rapid absorption by plants, root uptake from soil, or both (Culbreath et al., 1993). Even though benomyl is a systemic fungicide that can move acropetally in plants, it is not translocated into developing blossoms at an effective level. This is probably because its distribution within a plant depends upon the transpiration rate and bean petals have no stomata (Hunter et 
Chemigation with benomyl and fluazinam and fungicidal effects of them ...

TABLE 3 - Angular leaf spot severity at 93 DAE of beans (Phaseolus vulgaris) treated with fungicides ${ }^{\mathrm{a}}$ via three modes of application in Viçosa, MG, 1999

\begin{tabular}{|c|c|c|c|c|}
\hline \multirow{2}{*}{ Treatment } & \multirow{2}{*}{$\begin{array}{c}\text { Water Volume } \\
\left(\mathrm{l} \mathrm{ha}^{-1}\right)\end{array}$} & \multicolumn{2}{|c|}{ Angular leaf spot ${ }^{\mathrm{b}, \mathrm{c}}$} & \multirow{2}{*}{$\mathbf{L S D}^{d}$} \\
\hline & & Fluazinam & Benomyl & \\
\hline Untreated control & & \multicolumn{2}{|c|}{3.4} & \\
\hline Fungicide in soil & 35,000 & $3.2 \mathrm{a}$ & $2.9 \mathrm{a}^{\mathrm{e}}$ & NS \\
\hline Chemigation & 35,000 & $3.0 \mathrm{a}$ & $2.0 \mathrm{~b}^{\mathrm{e}}$ & 0.36 \\
\hline Backpack sprayer & 667 & $2.3 \mathrm{~b}^{\mathrm{e}}$ & $2.1 \mathrm{~b}^{\mathrm{e}}$ & NS \\
\hline
\end{tabular}

${ }^{a}$ Two applications of Frowncide 500 SC $\left(0.51\right.$ a.i. ha $\left.{ }^{-1}\right)$ or Benlate 500 $\left(1.0 \mathrm{~kg}\right.$ a.i. ha $\left.{ }^{-1}\right)$ at 47 and 61 DAE.

${ }^{\mathrm{b}}$ Based on a 1-9 scale of severity, where 1.1 to 2.5 (low) and 2.6 to 4.1 (low/moderate).

' Means separation by Fisher's protected LSD test at 5\% level.

d For comparison of fungicides within modes of application, Fisher's protected LSD $(\mathrm{P}<0.05)$. NS = not significant.

${ }^{e}$ Different from untreated control by Dunnett's test at 5\% level.

al., 1978). On the other hand, benomyl systemic action could control foliar diseases, as was noted in our study in relation to angular leaf spot. Fluazinam has a protective action, with little curative and systemic activity (Tomlin, 1994).

According to Yarden et al. (1986) benomyl applied to the soil reduced sclerotial germination, apothecial formation, rate of apothecial production, and delay in apothecial emergence. Oliveira et al. (1999) added that fluazinam is more efficient than benomyl on inhibition of myceliogenic germination of sclerotia and on growth of stipes from apothecia. This could explain the control of white mold provided by fluazinam when applied only to the soil. In a preliminary study, Vieira et al. (2001) observed that fluazinam applied only on soil reduced white mold incidence and the amount of sclerotia produced. The effects of fungicide on the fungus structures presente in soil might result in a shortened period of host exposure to the pathogen throughout the growing season. Yarden et al. (1986) reported that benomyl-thiram combinations were more effective than either fungicide alone when applied in soil for white mold control. When thiram is applied to soil along with benomyl degradation of the latter is delayed thus increasing persistence of the compound fungicidal activity in soil.

Benomyl is rapidly converted to carbendazim in the environment (Tomlin, 1994), and both have relatively low mobility in soil (Solel et al., 1979). This fact can be advantageous when attempting to control $S$. sclerotiorum in soil, once sclerotial germination is usually restricted to top soil layers (1-3 cm). Yarden et al. (1986) showed that $74 \%$ of fungitoxic compounds of benomyl remained within the upper $2.5 \mathrm{~cm}$ of a sand loam soil profile when it was applied with the equivalent to $25 \mathrm{~mm}$ of water.

Our results suggest that benomyl and fluazinam are efficient when fungigated, and that fluazinam can control white mold when applied in soil. More research is needed on the relationship of soil moisture, time of pesticide application, volume of water to use during application, fungicide combinations, and inhibitory or stimulatory effects on nontarget organisms. However, the data presented here help to explain white mold control results observed in the field and provide clues for improvement of chemigation techniques.

\section{LITERATURE CITED}

ABAWI, G.S. \& GROGAN, R.G. Epidemiology of diseases caused by Sclerotinia sclerotiorum. Phytopathology 69:899-904. 1979.

BOLAND, G.J. \& HALL, R. Index of plant hosts of Sclerotinia sclerotiorum. Canadian Journal of Plant Pathology 16:93-108. 1994.

BRENNEMAN, T.B., SUMNER, H.R. \& HARRISON, G.W. Deposition and retention of chlorothalonil applied to peanut foliage: Effects of application methods, fungicide formulations and oil additives. Peanut Science 17:80-84. 1990.

CHEW, V. Comparing treatment means: a compedium. HortScience 11:348-356. 1976.

CSINOS, A.S., JOHNSON, A.W. \& GOLDEN, A.M. Metalaxyl and fenamiphos applied through irrigation water to control black shank/ root-rot complex on tabacco. Plant Disease. 70:210-213. 1986.

CULBREATH, A.K., BRENNEMAN, T.B., CHANDLER, L.D. \& SUMNER, H.R. Chemigation and ground-spray applications of cyproconazole for control of late leaf spot of peanut. Plant Disease 77:505-507. 1993.

FORSTER, R.L. \& SAMSON, R.G. Control of white mold of dry beans by fungicides applied via sprinkler irrigation. Annual Report Bean Improvement Cooperative 27:106. 1994.

HALL, R. \& PHILLIPS, L.G. Evaluation of parameters to assess resistance of white bean to white mold. Annual Report Bean Improvement Cooperative 39:306-307. 1996.

HUNTER, J.E., ABAWI, G.S. \& CROSIER, D.C. Effects of timing, coverage, and spray oil on control of white mold of snap bean with benomyl. Plant Disease Report 62:633-637. 1978.

MCMASTER, G.M. \& DOUGLAS, D.R. Fungicide application through sprinkler irrigation systems. Transactions of the ASAE 19:1041-1044. 1976.

OLIVEIRA, S.H.F., KIMATI, H. \& TOFOLI, J.G. Ação diferencial de fungicidas no ciclo de vida de Sclerotinia sclerotiorum do feijoeiro. Summa Phytopathologica 25:256-261. 1999.

OLIVEIRA, S.H.F., RECCO, C.A., SUGAHARA, E. \& OLIVEIRA, D.A. Avaliação comparativa da fungigação e aplicação convencional de fungicidas para controle de Sclerotinia sclerotiorum em feijoeiro. Summa Phytopathologica 21:249-252. 1995.

SCHWARTZ, H.F., STEADMAN, J.R., WYSONG, D.S. \& KERR, E.D. White Mold of Dry Beans. Fort Collins. Colorado State University Cooperative Extension. 1989.

SOLEL, Z., SANDLER, D. \& DINOOR, A. Mobility and persistence of carbendazim and thiabendazole applied to soil via drip irrigation. Phytopathology 69:1273-1277. 1979.

TOMLIN, C. The Pesticide Manual. Surrey. British Crop Protection Council. 1994.

TU, J.C. Epidemiology of white mold (Sclerotinia sclerotiorum) in navy bean (Phaseolus vulgaris). Mededelingen van de Faculteit Landbouwwetenschappen Rijksuniversiteit Gent 52:787-796. 1987.

TU, J.C. Management of white mold of white bean in Ontario. Plant Disease 73:281-285. 1989.

VAN SCHOONHOVEN, A. \& PASTOR CORRALES, M.A. Standard System for Evaluation of Bean Germoplasm. Cali. CIAT. 1987. 


\section{R.F. Vieira et al.}

VIEIRA, R.F. Introdução à quimigação. In: Costa, E.F. da, Vieira, R.F. \& Viana, P.A. (Eds.). Quimigação, Aplicação de Produtos Químicos e Biológicos via Irrigação, Brasília. EMBRAPA-SPI. 1994. pp.13-39.

VIEIRA, R.F. \& SUMNER, D.S. Application of fungicides to foliage through overhead sprinkler irrigation - a review. Pesticide Science 53:412-422. 1999.

VIEIRA, R.F., PAULA JÚNIOR, T.J de; PERES, A.P. \&
MACHADO, J. da C. Fungicidas aplicados via água de irrigação no controle do mofo-branco no feijoeiro e incidência do patógeno na semente. Fitopatologia Brasileira 26:770-773. 2001.

YARDEN, O., BEN-YEPHET, Y., KATAN, J. \& AHARONSON, N. Fungicidal control of Sclerotinia sclerotiorum in soil with a combination of benomyl and thiram. Plant Disease 70:738-742. 1986. 